\title{
Hypothalamic leptin gene therapy reduces body weight without accelerating age-related bone loss
}

\author{
Russell T Turner ${ }^{1,2}$, Michael Dube ${ }^{3}$, Adam J Branscum ${ }^{4}$, Carmen P Wong', \\ Dawn A Olson', Xiaoying Zhong', Mercedes F Kweh ${ }^{5}$, Iske V Larkin ${ }^{6}$, \\ Thomas J Wronski ${ }^{5}$, Clifford J Rosen ${ }^{7}$, Satya P Kalra ${ }^{3}$ and Urszula T Iwaniec ${ }^{1,2}$ \\ ${ }^{1}$ Skeletal Biology Laboratory, School of Biological and Population Health Sciences, Oregon State University, \\ Corvallis, Oregon 97331, USA \\ ${ }^{2}$ Center for Healthy Aging Research, Oregon State University, Corvallis, Oregon, USA \\ ${ }^{3}$ Department of Neuroscience, McKnight Brain Institute, University of Florida, Gainesville, Florida, USA \\ ${ }^{4}$ Biostatistics, School of Biological and Population Health Sciences, Oregon State University, Corvallis, Oregon, USA \\ ${ }^{5}$ Department of Physiological Sciences, University of Florida, Gainesville, Florida, USA \\ ${ }^{6}$ Department of Large Animal Clinical Sciences, University of Florida, Gainesville, Florida, USA \\ ${ }^{7}$ Maine Medical Center Research Institute, Scarborough, Maine, USA
}

\author{
Correspondence \\ should be addressed \\ to U T Iwaniec \\ Email \\ urszula.iwaniec@ \\ oregonstate.edu
}

\begin{abstract}
Excessive weight gain in adults is associated with a variety of negative health outcomes. Unfortunately, dieting, exercise, and pharmacological interventions have had limited long-term success in weight control and can result in detrimental side effects, including accelerating age-related cancellous bone loss. We investigated the efficacy of using hypothalamic leptin gene therapy as an alternative method for reducing weight in skeletally-mature (9 months old) female rats and determined the impact of leptin-induced weight loss on bone mass, density, and microarchitecture, and serum biomarkers of bone turnover (CTx and osteocalcin). Rats were implanted with cannulae in the 3rd ventricle of the hypothalamus and injected with either recombinant adeno-associated virus encoding the gene for rat leptin (rAAV-Leptin, $n=7$ ) or a control vector encoding green fluorescent protein (rAAV-GFP, $n=10)$ and sacrificed 18 weeks later. A baseline control group $(n=7)$ was sacrificed at vector administration. $\mathrm{rAAV}$-Leptin-treated rats lost weight $(-4 \pm 2 \%)$ while rAAV-GFP-treated rats gained weight $(14 \pm 2 \%)$ during the study. At study termination, rAAV-Leptin-treated rats weighed $17 \%$ less than rAAV-GFP-treated rats and had lower abdominal white adipose tissue weight $(-80 \%)$, serum leptin $(-77 \%)$, and serum IGF1 $(-34 \%)$. Cancellous bone volume fraction in distal femur metaphysis and epiphysis, and in lumbar vertebra tended to be lower $(P<0.1)$ in rAAV-GFP-treated rats ( 13.5 months old) compared to baseline control rats ( 9 months old). Significant differences in cancellous bone or biomarkers of bone turnover were not detected between rAAV-Leptin and rAAV-GFP rats. In summary, rAAV-Leptin-treated rats maintained a lower body weight compared to baseline and rAAV-GFP-treated rats with minimal effects on bone mass, density, microarchitecture, or biochemical markers of bone turnover.
\end{abstract}

\section{Key Words}

- rAAV-Leptin

- microcomputed tomography

- dual energy absorptiometry

- white adipose tissue
Journal of Endocrinology (2015) 227, 129-141 Printed in Great Britain
Published by Bioscientifica Ltd. 


\section{Introduction}

Insidious excessive weight gain is common in adults and is associated with increased risk for various chronic diseases, including heart disease, chronic obstructive pulmonary disease, type 2 diabetes, osteoarthritis and certain cancers (Franssen et al. 2008, Magliano 2008, Low et al. 2009). Weight loss, whether induced by caloric restriction alone or in combination with exercise and/or pharmaceutical intervention, may attenuate or reverse the health risks associated with excessive weight gain. Unfortunately, the long-term efficacy of conventional weight loss interventions is generally poor and many individuals weight cycle through repetitive bouts of weight loss followed by rapid weight regain (Elfhag \& Rossner 2005, Wu et al. 2009, Yaskin et al. 2009).

The adipokine leptin plays an essential role in energy homeostasis (Rosenbaum \& Leibel 2014) and adult-onset weight gain is closely associated with an increase in circulating leptin and development of leptin resistance (Scarpace \& Tumer 2001, Morris \& Rui 2009, Knobelspies et al. 2010, Carter et al. 2013). As a consequence, avoiding leptin resistance may be essential to achieving lifelong weight control. However, the mechanisms mediating leptin resistance are incompletely understood. To date, studies suggest that high blood leptin concentrations result in saturation of leptin transport across the blood brain barrier (blood brain barrier resistance) (Banks \& Lebel 2002) and/or down regulation of leptin signaling in the hypothalamus due to constitutive expression of suppressor of cytokine signaling (hypothalamic resistance) (Bjorbaek et al. 1998).

Delivery of leptin directly into the hypothalamus by gene therapy normalizes body weight and extends lifespan in morbidly obese leptin-deficient ob/ob mice in the absence of detectable circulating leptin (Dhillon et al. 2000, Boghossian et al. 2007). Additionally, hypothalamic leptin gene therapy slows weight gain in rodents capable of producing leptin (Boghossian et al. 2005). These findings suggest that increasing leptin levels directly in the hypothalamus, in addition to bypassing blood brain barrier-mediated leptin resistance, overcomes hypothalamic leptin resistance. However, it is less clear whether this approach can induce weight loss and/or maintain lower body weight in aging rodents with normal circulating levels of the hormone (Shapiro et al. 2008).

In humans, calorie restriction-induced weight loss is often associated with bone loss, leading to increased risk for osteoporosis (Shapses \& Riedt 2006, Lee et al. 2010a). Importantly, weight regain does not restore bone and, as a consequence, weight cycling is especially deleterious to the skeletal system (Lee et al. 2010a, Villalon et al. 2011). Because osteoporotic fractures are associated with decreased quality of life and increased mortality (Cauley 2013), there is strong incentive to develop weight loss strategies that preserve bone mass.

Leptin is a candidate factor for coupling bone metabolism to energy availability. Leptin is required for normal skeletal growth, maturation and turnover (Gat-Yablonski \& Phillip 2008, Arounleut et al. 2013, Turner et al. 2013a, 2014). Weight loss results in decreased leptin levels (Hamann \& Matthaei 1996), reduced bone accrual during growth (Devlin et al. 2010), and accelerated age-related bone loss (Talbott et al. 2001, Turner \& Iwaniec 2011). Importantly, leptin treatment attenuates the inhibitory effects of caloric restriction on bone growth (Goldstone et al. 2002, Gat-Yablonski et al. 2004). Furthermore, leptin administered at supraphysiological levels has been reported to maintain bone mineral density despite inducing weight loss (Stunes et al. 2012).

Taken together, the previous findings suggest the respective skeletal changes accompanying caloric restriction-induced weight loss and leptin-induced weight loss differ. Specifically, low hypothalamic leptin levels induced by caloric restriction lead to an adaptive response similar to starvation and result in rapid bone loss. In contrast, elevating hypothalamic leptin levels decreases appetite and increases energy expenditure (Friedman 2010) leading to weight loss with minimal impact on the skeleton. Although suggestive, the aforementioned conclusions are based on short-term studies where leptin was administered subcutaneously to growing rats with relatively low levels of circulating leptin. It is less clear whether similar benefits can be achieved in skeletally mature animals exhibiting weight gain as well as age-related bone loss. As such, the present study was designed to determine the long-term efficacy of increased hypothalamic leptin in reducing adult onset-associated weight gain and the impact this intervention has on bone mass, density, and architecture.

\section{Material and methods}

\section{Animals}

Nine-month-old female Sprague Dawley rats (Harlan; Indianapolis, IN, USA) were used in the experiment. The rats were maintained in accordance with the NIH Guide for the Care and Use of Laboratory Animals and the

Published by Bioscientifica Ltd. 
experimental protocol was approved (IACUC \#D642) by the Institutional Animal Care and Use Committee at the University of Florida (Gainesville, FL, USA).

\section{Experimental design}

The rats were randomized by weight into three groups: baseline control $(n=7)$, rAAV-GFP control $(n=10)$, and rAAV-Leptin $(n=7)$. The baseline group (body weight; $289 \pm 7 \mathrm{~g}$, mean \pm s.E.M.) was sacrificed at vector administration. The rAAV-GFP and rAAV-Leptin groups were sacrificed at 18 weeks post-vector administration. All rats were housed individually in a temperature $\left(21-23^{\circ} \mathrm{C}\right)$ and light-controlled (lights on 0800-1800 h) room under specific pathogen-free conditions. Food and water were available ad libitum to all animals. The rats were weighed and food consumption determined weekly.

\section{Construction and packaging of rAAV vectors}

The rAAV-Leptin and rAAV-GFP vectors were constructed and packaged as described previously (Beretta et al. 2002). In brief, the vector pTR-CBA-Ob EcoRI fragment of pCRrOb (a gift from Dr Roger $\mathrm{H}$ Unger, University of Texas Southwestern Medical Center, Dallas, TX, USA) containing rat leptin cDNA was subcloned into rAAV vector plasmid pAAV $\beta G E n h$ after deleting the EcoRI fragment carrying the $\beta$-glucoronidase cDNA sequence (Zolotukhin et al. 1999, Dhillon 2000, Dhillon et al. 2000, 2001a). The control vector, rAAV-GFP, was similarly constructed to encode the GFP gene (Zolotukhin et al. 1999, Dhillon 2000, Dhillon et al. 2001a, Dube et al. 2002).

\section{Vector administration}

For vector administration, the rats were anesthetized with $2-3 \%$ isoflurane delivered in oxygen and stereotaxically implanted with a permanent cannula in the $3^{\text {rd }}$ cerebroventricle. The coordinates employed for cannula placement were based on the rat brain atlas. After 1 week of recovery, rats were injected once intracerebroventricularly with either rAAV-GFP $\left(5 \mu \mathrm{l}, 8.25 \times 10^{11}\right.$ virus particles) or rAAV-Leptin $\left(5 \mu \mathrm{l}, 7.7 \times 10^{11}\right.$ virus particles).

\section{Tissue collection and analyses}

Rats were fasted overnight prior to tissue collection. For tissue collection, the rats were anesthetized with 2-3\% isoflurane delivered in oxygen. Blood was collected from abdominal aorta and serum stored at $-20^{\circ} \mathrm{C}$ for analysis of leptin, insulin-like growth factor 1 (IGF1), growth hormone, glucose, adiponectin, collagen type 1 crosslinked C-telopeptide (CTx), and osteocalcin. Death was induced by decapitation. Hypothalami were excised and stored in RNAlater (Ambion, Austin, TX, USA) for analysis of leptin and NPY mRNA levels. Abdominal white adipose tissue (WAT) was excised and weighed and samples of WAT were stored in RNAlater for analysis of leptin and IGF1 mRNA levels. Femora and 2nd lumbar vertebrae were collected and stored in 70\% ethanol for analysis of bone mass, density, and architecture.

\section{Serum chemistry}

Serum glucose was measured using Autokit Glucose (Wako, Richmond, VA, USA). Serum leptin was assayed using the rat leptin RIA kit from Linco Research, Inc. (St Louis, MO, USA) according to the manufacturer's instructions. Serum IGF1 was measured with a RIA using a polyclonal antibody to IGF1 after separation of IGFbinding proteins by acid ethanol extraction. Serum osteocalcin was measured using rat Gla-osteocalcin high sensitive EIA kit (Clontech, Mountain View, CA, USA). Serum CTx was measured using rat CTx-I ELISA kit (Novateinbio, Cambridge, MA, USA). Serum adiponectin was measured using rat total adiponectin Quantikine ELISA kit (R\&D Systems, Minneapolis, MN, USA). Serum growth hormone was measured using a rat/mouse growth hormone ELISA kit (EMB Millipore, Billerica, MA, USA).

\section{RNA analysis}

Tissue samples were homogenized in TRIzol reagent (Invitrogen, Carlsbad, CA, USA). Total cellular RNA was isolated according to manufacturer's protocol. RNA quantity was determined spectrophotometrically and RNA quality was evaluated via formaldehyde agarose gel electrophoresis.

\section{Real-Time PCR}

cDNA for RT-PCR was synthesized using SuperScript First-Strand Synthesis System for RT-PCR (Invitrogen). One microgram of total RNA was reverse transcribed using random hexamer primers and SuperScript II reverse transcriptase according to manufacturer's protocol. Real-time PCR primers that are specific for rat leptin (forward: 5'- CCTGTGGCTTTGGTCCTATCTG-3', reverse: 5'- AGGCAAGCTGGTGAGGATCTG-3'), NPY (forward: 5'-GCCATGATGCTAGGTAACAAACG-3', reverse: 5'-GTTTCATTTCCCATCACCACATG-3'), IGF1 (forward: 5'- CCGGACCAGAGACCCTTTG-3', reverse: 5'- CCTGTGGGCTTGTTGAAGTAAAA-3'), and $18 \mathrm{~S}$ ribosomal RNA (18S)

Published by Bioscientifica Ltd. 
(forward: 5'- GGACCAGAGCGAAAGCATTTGC-3', reverse: 5' - CGCCAGTCGGCATCGTTTATG-3') were synthesized by Operon Biotechnologies (Huntsville, AL, USA). Real-time PCR reactions were performed using DyNAmo HS SYBR Green qPCR kit (New England Biolabs, Ipswich, MA, USA). A standard curve that was generated from serial dilutions of purified plasmid DNA that encoded the respective genes was used to measure mRNA transcript copy number. mRNA data represent normalized copy number using $18 \mathrm{~S}$ ribosomal RNA gene.

\section{Dual Energy X-ray absorptiometry}

Total femur bone mineral content (BMC, $\mathrm{g})$, area $\left(\mathrm{cm}^{2}\right)$, and bone mineral density (BMD, $\mathrm{g} / \mathrm{cm}^{2}$ ) were measured ex vivo using dual energy absorptiometry (DXA; Piximus 2, Lunar Corp., Madison, WI, USA).

\section{Microcomputed tomography}

Microcomputed tomography $(\mu \mathrm{CT})$ was used for nondestructive high resolution 3-dimensional evaluation of cortical and cancellous bone volume and architecture. Midshaft and distal femora and 2nd lumbar vertebrae were scanned in $70 \%$ ethanol using a Scanco $\mu$ CT40 scanner (Scanco Medical AG, Basserdorf, Switzerland) at a voxel size of $16 \times 16 \times 16 \mu \mathrm{m}\left(55 \mathrm{kV}_{\mathrm{p}} \mathrm{X}\right.$-ray voltage, $145 \mu \mathrm{A}$ intensity, and $200 \mathrm{~ms}$ integration time). Filtering parameters sigma and support were set to 0.8 and 1 respectively. Bone segmentation was conducted at a threshold of 245 (scale, 0-1000) determined empirically. Cortical bone in the mid femur diaphysis and cancellous bone in the distal femur metaphysis and epiphysis were evaluated. Automated contouring was used to delineate cortical bone from non-bone. Following, all cortical slices were examined visually for inclusion of cancellous struts originating from the endocortex (extremely rare at this site) and manually removed when present. Twenty consecutive slices $(320 \mu \mathrm{m})$ of bone were evaluated and cross-sectional volume (cortical and marrow volume, $\left.\mathrm{mm}^{3}\right)$, cortical volume $\left(\mathrm{mm}^{3}\right)$, marrow volume $\left(\mathrm{mm}^{3}\right)$, and cortical thickness $(\mu \mathrm{m})$ were measured. Polar moment of inertia $\left(\mathrm{I}_{\text {Polar }}\right)$ was determined as a surrogate measure of bone strength in torsion. For the femoral metaphysis, 75 consecutive slices $(1200 \mu \mathrm{m})$ of cancellous bone, 150 slices $(2400 \mu \mathrm{m})$ proximal to the growth plate, were evaluated. The entire cancellous compartment $(60 \pm 1$ slices, $960 \pm$ $16 \mu \mathrm{m}$, mean \pm s.e.m.) was assessed in the femoral epiphysis. Analysis of lumbar vertebra included the entire region of cancellous bone between the cranial and caudal growth plates $(282 \pm 2$ slices, $4,512 \pm 36 \mu \mathrm{m})$. Manual contouring was used to delineate cancellous from cortical bone in the femur metaphysis, femur epiphysis, and vertebral body. Direct cancellous bone measurements included cancellous bone volume fraction (bone volume/tissue volume, \%), connectivity density $\left(\mathrm{mm}^{-3}\right)$, trabecular thickness $(\mu \mathrm{m})$, trabecular number $\left(\mathrm{mm}^{-1}\right)$, and trabecular spacing $(\mu \mathrm{m})$ (Thomsen et al. 2005).

\section{Statistical analysis}

Mean responses were compared between three groups (baseline, rAAV-GFP, and rAAV-Leptin) using analysis of variance (ANOVA), while two-group comparisons were made using $t$-tests. A modified $F$ test was used when the assumption of equal variance was violated, with Welch's two-sample $t$-test used for two-group comparisons (Welch 1951). The Kruskal-Wallis nonparametric test was used when only the normality ANOVA assumption was violated, in which case the Wilcoxon-Mann-Whitney test was used for two-group comparisons. The required conditions for valid use of $t$-tests and ANOVA were assessed using Levene's test for homogeneity of variance, plots of residuals versus fitted values, normal quantile plots, and the Anderson-Darling test of normality. Longitudinal data on weekly measurements of body weight (weeks 0-18) and food intake (weeks 1-18) were analyzed using linear mixed models to account for correlated data. To accommodate different slopes for the rAAV-GFP and rAAV-Leptin groups and varying slope coefficients across time for these groups, the data on body weight were modeled using a random intercept linear spline model with a single knot at week 4 . The random intercept, random slope mixed model for food intake allowed for different marginal intercepts and slopes between the two groups. The Benjamini and Hochberg method for maintaining the false discovery rate at 5\% was used to adjust for multiple comparisons (Benjamini \& Hochberg 1995). Differences were considered significant at $P \leq 0.05$. Data are presented as mean \pm s.E.M. Data analysis was performed using $\mathrm{R}$ version 2.12 (Team 2010).

\section{Results}

The effects of hypothalamic rAAV-Leptin gene therapy on body weight, abdominal WAT weight, and food intake are shown in Fig. 1. rAAV-Leptin-treated rats lost weight $(-4 \pm 2 \%)$ during the 18 week duration of study. The estimated decrease in mean weight from weeks 0 to 18 was

Published by Bioscientifica Ltd. 

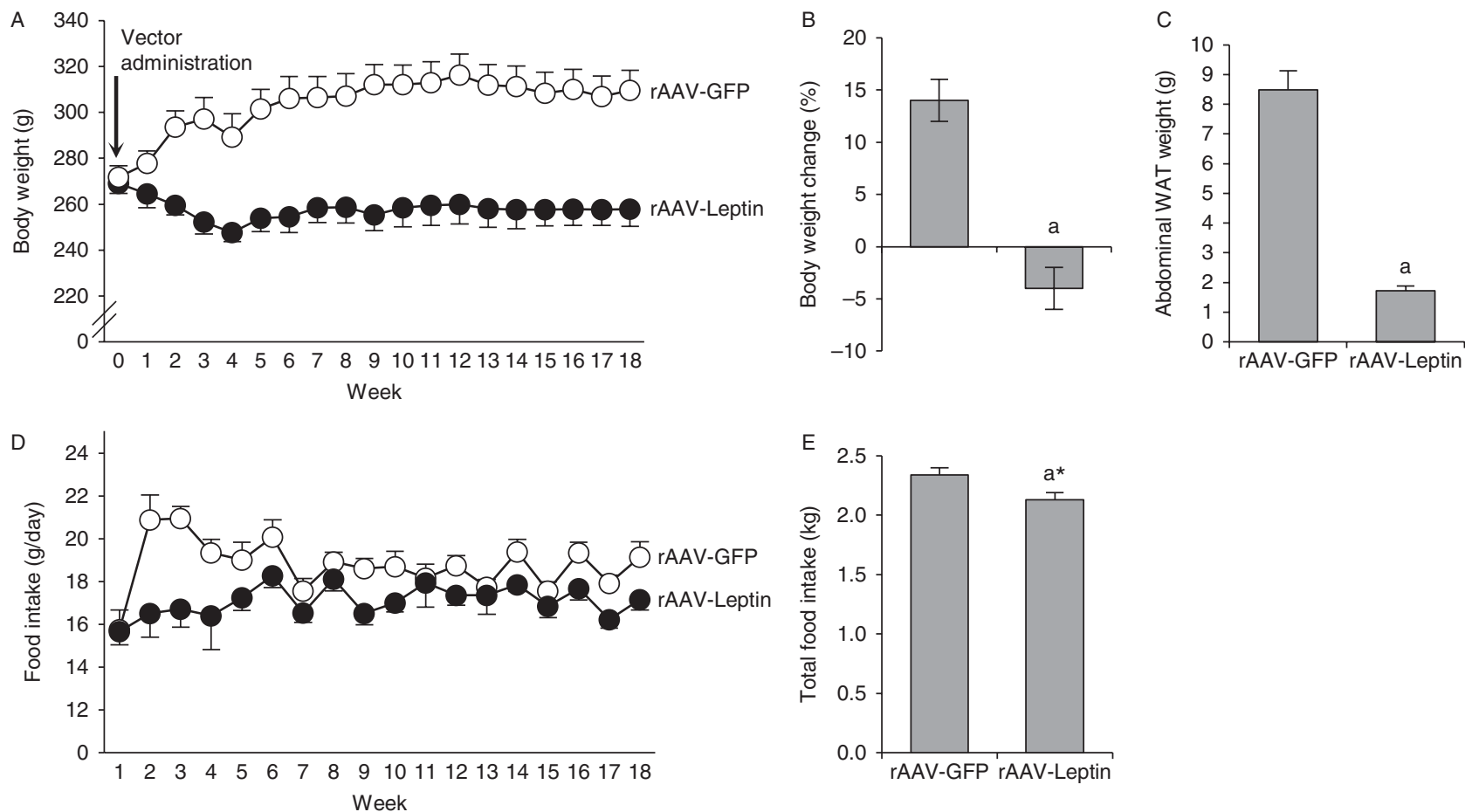

Figure 1

Effects of increased hypothalamic leptin via rAAV-Leptin therapy on body weight over time (A), body weight change (B), abdominal white adipose tissue (WAT) weight (C), food intake over time (D), and cumulative food

$8 \pm 3 \mathrm{~g}(P=0.006 ; 95 \% \mathrm{CI}: 2 \mathrm{~g}, 13 \mathrm{~g})$. The weight loss in the rAAV-Leptin group occurred during the initial 4 weeks post-vector administration (estimated slope: -3.6 , $P<0.0001 ; 95 \%$ CI: $-5.2,-2.1)$ with weight increasing thereafter (estimated slope: $0.5, P=0.01 ; 95 \%$ CI: 0.12 , 0.85 ) (Fig. $1 \mathrm{~A}$ and $\mathrm{B}$ ). In contrast, control rAAV-GFPtreated rats gained weight $(14 \pm 2 \%)$ during the study. The estimated increase in mean weight from weeks 0 to 18 was $40 \pm 2 \mathrm{~g}(P=0.006 ; 95 \% \mathrm{CI}: 36,45)$. The increase in weight was greater during the first 4 weeks following vector administration (estimated slope: 7.7, $P<0.0001 ; 95 \%$ CI: $6.4,9.0)$ than during the subsequent 13 weeks (estimated slope: $0.7, P<0.0001 ; 95 \%$ CI: $0.39,1.01)$. The rate of change in body weight (i.e. slope) differed between rAAVGFP-treated and rAAV-Leptin-treated rats during the first 4 weeks of treatment $(P<0.0001)$ but not during the subsequent 13 weeks. At study termination, rAAVLeptin-treated rats weighed $17 \%$ less $(53 \pm 10 \mathrm{~g}$; $P<0.0001 ; 95 \%$ CI: 32, 74) than the rAAV-GFP-treated rats. This difference in body weight was associated with a pronounced reduction in abdominal WAT. WAT weight was $80 \%$ lower in rAAV-Leptin-treated compared to rAAV-GFP-treated rats (Fig. 1C). intake (E). Values are mean \pm s.E.M., $n=7-10 /$ group. ${ }^{a}$ Different from rAAVGFP, $P \leq 0.05$. ${ }^{a^{*}}$ Different from rAAV-GFP, $p<0.1$.

Food consumption was lower in rAAV-Leptin-treated rats compared to rAAV-GFP-treated rats (Fig. 1D). Although significant differences in food intake were not detected between the two groups at 1 week post-vector administration, the estimated difference in mean food intake between the two groups during weeks $2-4$ was 2.4 g/day $(P<0.0001 ; 95 \%$ CI: 1.6, 3.3). Food intake averaged $17.1 \mathrm{~g} /$ day $(95 \% \mathrm{CI}: 16.2,17.9)$ in the leptin group and $19.5 \mathrm{~g} /$ day $(95 \% \mathrm{CI}: 18.8,20.2)$ in the GFP group $(P<0.0001)$. For weeks $5-18$, the difference in food intake was still significant $(P=0.002)$, but the estimated difference dropped to $1.3 \mathrm{~g} /$ day $(95 \%$ CI: 0.5, 2.1). Food intake averaged $17.2 \mathrm{~g} /$ day (95\% CI: $16.4,17.9$ ) in the leptin group and $18.5 \mathrm{~g} /$ day $(95 \% \mathrm{CI}: 17.9,19.1)$ in the GFP group. Total food intake over the 18 week duration was $9 \%$ lower $(P=0.071)$ in the rAAV-Leptin group compared to the rAAV-GFP group (Fig. 1E).

The effects of rAAV-Leptin gene therapy on leptin and NPY mRNA expression in hypothalamus and leptin and IGF1 mRNA expression in abdominal WAT are shown in Fig. 2. As expected, rAAV-Leptin-treated rats had higher hypothalamic leptin mRNA levels than rAAV-GFP-treated rats (Fig. 2A). Significant differences in NPY mRNA

Published by Bioscientifica Ltd 

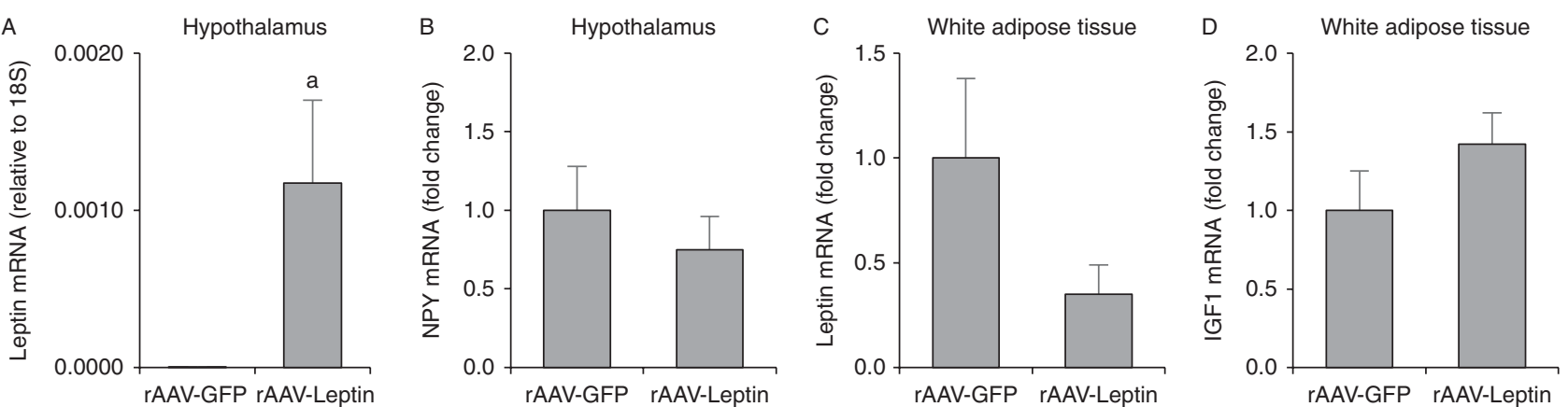

Figure 2

Effects of increased hypothalamic leptin via rAAV-Leptin therapy on leptin (A) and NPY (B) mRNA expression in hypothalamus, and leptin (C) and IGF1 (D) mRNA expression in abdominal white adipose tissue. Values are mean \pm s.E.M., $n=7-10 / g$ roup. ${ }^{a}$ Different from rAAV-GFP, $P \leq 0.05$.

expression in hypothalamus were not detected with treatment (Fig. 2B). Significant differences were also not detected with treatment for leptin and IGF1 mRNA expression in abdominal WAT (Fig. 2C and D).

The effects of rAAV-Leptin gene therapy on serum leptin, IGF1, growth hormone, glucose, adiponectin, CTx, and osteocalcin are shown in Fig. 3. Serum leptin and IGF1 concentrations were lower in rAAV-Leptin-treated rats compared to rAAV-GFP-treated rats (Fig. 3A and B). Significant differences between rAAV-Leptin-treated and
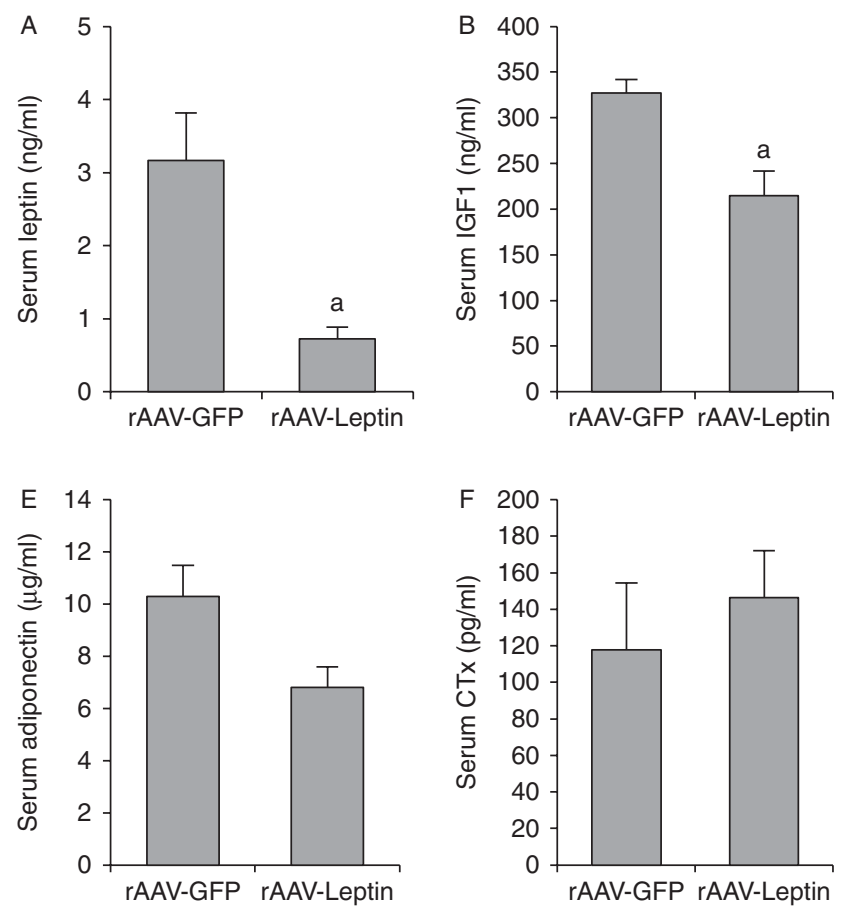

rAAV-GFP-treated rats were not detected for growth hormone (Fig. 3C), glucose (Fig. 3D), or adiponectin (Fig. 3E). Furthermore, significant differences between the 2 treatment groups were not detected for CTx, a marker of bone resorption (Fig. 3F) or osteocalcin, a marker of bone turnover (Fig. 3G).

The effects of rAAV-Leptin gene therapy on femur area, BMC, and BMD are shown in Fig. 4. Bone area tended to be higher in rAAV-GFP-treated rats (13.5 months old) compared to baseline control rats ( 9 months old; $P=0.072$ ) and rAAV-
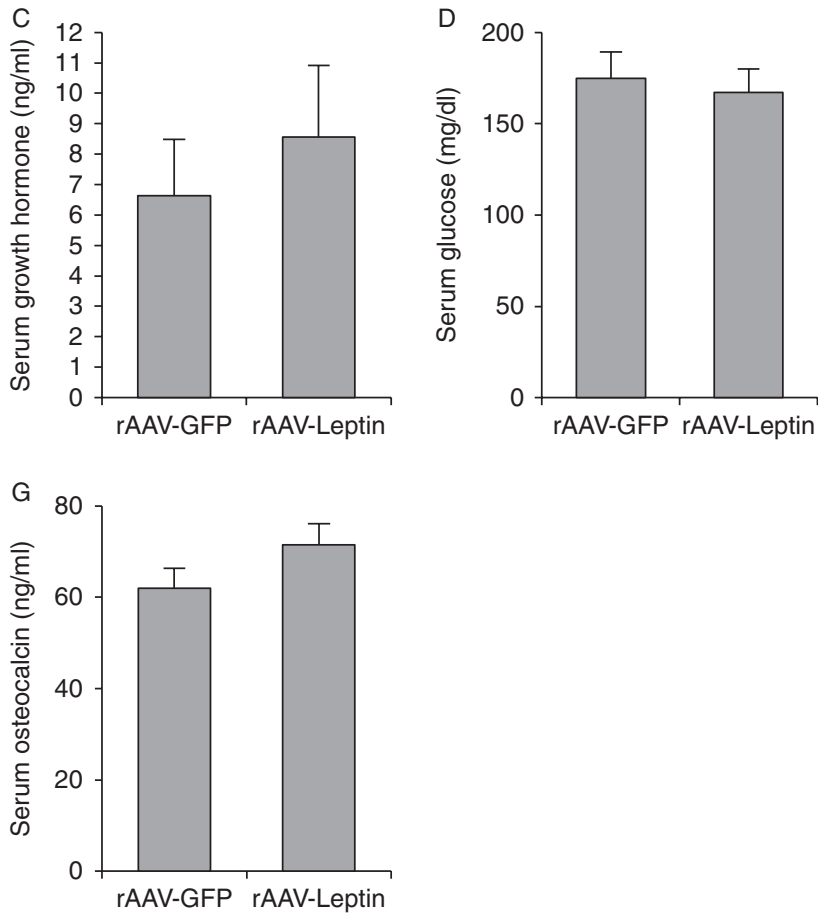

\section{Figure 3}

Effects of increased hypothalamic leptin via rAAV-Leptin therapy on serum leptin (A), IGF1 (B), growth hormone (C), glucose (D), adiponectin (E), CTx (F), and osteocalcin (G). Values are mean \pm s.E.M., $n=7-10 /$ group. ${ }^{a}$ Different from rAAV-GFP, $P \leq 0.05$.

(C) 2015 Society for Endocrinology Printed in Great Britain 

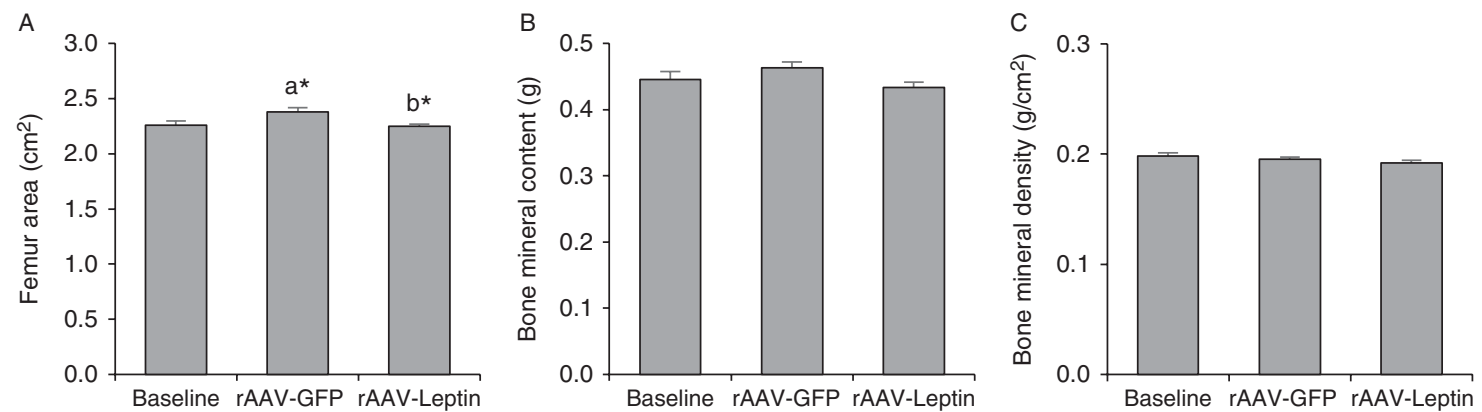

\section{Figure 4}

Effects of increased hypothalamic leptin via rAAV-Leptin therapy on femur area (A), bone mineral content (B), and bone mineral density (C). Values are mean \pm S.E.M., $n=7-10 /$ group. ${ }^{a^{*}}$ Different from Baseline, $P<0.1 .{ }^{b^{*}}$ Different from rAAV-GFP, $P<0.1$

Leptin-treated rats (13.5 months old; $P=0.056)$. Significant differences in bone area were not detected between rAAVLeptin-treated rats and baseline control rats. Significant differences in either BMC or BMD were not detected among baseline, rAAV-GFP, and rAAV-Leptin rats.

The effects of rAAV-Leptin gene therapy on cortical bone in the femoral diaphysis and cancellous bone in the femoral metaphysis and epiphysis are shown in Table 1.

\section{Femur diaphysis}

We found that 13.5-month-old rAAV-GFP-treated rats had greater cortical volume and tended to have greater polar moment of inertia $(P=0.072)$ than 9 -month-old baseline control rats. Cross-sectional volume, cortical volume, and polar moment of inertia also tended to be greater $(P=0.058$, $P=0.071$, and $P=0.056$ respectively) in rAAV-GFP-treated rats compared to rAAV-Leptin-treated rats. Significant differences between 13.5-month-old rAAV-Leptin-treated rats and 9-month-old baseline control rats were not detected for any of the cortical endpoints evaluated. Significant differences in marrow volume and cortical thickness were not detected among the three groups.

\section{Distal femur metaphysis}

We found that 13.5-month-old rAAV-GFP-treated rats had lower connectivity density and tended to have lower

Table 1 Effects of hypothalamic rAAV-Leptin therapy on cortical bone architecture in the femoral diaphysis and cancellous bone volume fraction (bone volume/tissue volume) and cancellous bone architecture in distal femur metaphysis and epiphysis

\begin{tabular}{l}
\hline Endpoint \\
\hline Femur Diaphysis (cortical bone) \\
Cross-sectional volume $\left(\mathrm{mm}^{3}\right)$ \\
Cortical volume $\left(\mathrm{mm}^{3}\right)$ \\
Marrow volume $\left(\mathrm{mm}^{3}\right)$ \\
Cortical thickness $(\mu \mathrm{m})$ \\
I polar $\left(\mathrm{mm}^{4}\right)$ \\
Distal Femur Metaphysis (cancellous bone) \\
Bone volume/tissue volume $(\%)$ \\
Connectivity density $\left(1 / \mathrm{mm}^{3}\right)$ \\
Trabecular number $(1 / \mathrm{mm})$ \\
Trabecular thickness $(\mu \mathrm{m})$ \\
Trabecular spacing $(\mu \mathrm{m})$ \\
Distal Femur Epiphysis $(\mathrm{cancellous} \mathrm{bone)}$ \\
Bone volume/tissue volume $(\%)$ \\
Connectivity density $\left(1 / \mathrm{mm}^{3}\right)$ \\
Trabecular number $(1 / \mathrm{mm})$ \\
Trabecular thickness $(\mu \mathrm{m})$ \\
Trabecular spacing $(\mu \mathrm{m})$ \\
\hline
\end{tabular}

\begin{tabular}{c}
\hline Baseline \\
\hline \\
$3.09 \pm 0.08$ \\
$2.01 \pm 0.04$ \\
$1.08 \pm 0.04$ \\
$724 \pm 8$ \\
$14.60 \pm 0.73$
\end{tabular}

$28.0 \pm 3.4$

$92.9 \pm 5.6$

$4.6 \pm 0.2$

$78 \pm 4$

$214 \pm 11$

$42.4 \pm 1.0$

$39.0 \pm 2.1$

$3.9 \pm 0.1$

$108 \pm 1$

$241 \pm 9$

\begin{tabular}{c}
\hline rAAV-GFP \\
\hline \\
$3.29 \pm 0.06$ \\
$2.16 \pm 0.02^{\mathrm{b}}$ \\
$1.12 \pm 0.04$ \\
$753 \pm 7$ \\
$16.65 \pm 0.49^{\mathrm{c}}$
\end{tabular}

$18.1 \pm 2.3^{c}$

$59.3 \pm 7.4^{b}$

$3.8 \pm 0.2^{\mathrm{C}}$

$69 \pm 3$

$263 \pm 15^{c}$

$37.1 \pm 1.3^{c}$

$35.9+1.5$

$3.7 \pm 0.1$

$102 \pm 2$

$256 \pm 5$

rAAV-leptin

\section{FDR-adjusted $P$ value}

$3.05 \pm 0.06^{\mathrm{a}} \quad 0.072$

$2.05 \pm 0.04^{\mathrm{a}} \quad 0.056$

$1.00+0.04-0.182$

$748 \pm 13 \quad 0.135$

$14.46 \pm 0.58^{\mathrm{a}} \quad 0.071$

$20.9 \pm 1.5$

$70.6 \pm 5.6^{c} \quad 0.052$

$4.0+0.1^{\mathrm{c}} \quad 0.058$

$70 \pm 2 \quad 0.195$

$\begin{array}{ll}245 \pm 8^{c} & 0.087\end{array}$

$38.3 \pm 0.7^{\mathrm{b}} \quad 0.056$

$34.8+2.0 \quad 0.378$

$3.7 \pm 0.1 \quad 0.364$

$102+2 \quad 0.108$

$\begin{array}{ll}257 \pm 8 & 0.328\end{array}$

Data are mean \pm S.E.M.; $n=7-10$ /group.

a Different from rAAV-GFP, $P<0.1$.

${ }^{b}$ Different from Baseline, $P \leq 0.05$.

'Different from Baseline, $P<0.1$.

http://joe.endocrinology-journals.org DOI: 10.1530/JOE-15-0280
(C) 2015 Society for Endocrinology Printed in Great Britain 
cancellous bone volume fraction $(P=0.071)$ and trabecular number $(P=0.056)$ and greater trabecular spacing $(P=0.072)$ than 9 -month-old baseline control rats. Overall, 13.5-month-old rAAV-Leptin-treated rats tended to have lower connectivity density $(P=0.060)$ and trabecular number $(P=0.072)$ and greater trabecular spacing $(P=0.084)$ than 9 -month-old baseline control rats. Significant differences between rAAV-GFP and rAAV-Leptin rats were not detected for any of the cancellous endpoints evaluated. Significant differences in trabecular thickness were not detected among the three groups.

\section{Distal femur epiphysis}

Cancellous bone volume fraction tended to be lower $(P=0.056)$ in 13.5 -month-old rAAV-GFP-treated rats and was lower in 13.5-month-old rAAV-Leptin-treated rats than in 9-month-old baseline control rats. Significant differences in cancellous bone volume fraction were not detected between rAAV-GFP-treated and rAAV-Leptin-treated rats. Significant differences in connectivity density, trabecular number, trabecular thickness, and trabecular spacing were not detected among the three groups.

\section{Lumbar vertebra}

The effects of rAAV-Leptin gene therapy on cancellous bone in the lumbar vertebra are shown in Table 2. Overall, 13.5-month-old rAAV-GFP-treated rats tended to have lower cancellous bone volume fraction $(P=0.071)$ and trabecular number $(P=0.072)$ and greater trabecular spacing $(P=0.072)$ than 9-month-old baseline control rats. Significant differences in bone volume fraction, trabecular number, or trabecular spacing were not detected between rAAV-GFP-treated and rAAV-Leptin-treated rats. Significant differences among the 3 groups were not detected for connectivity density or trabecular thickness.

\section{Discussion}

The long-term effects of hypothalamic rAAV-Leptin gene therapy on energy balance and bone metabolism were evaluated in skeletally mature (9 month old) female rats. Consistent with previous studies (Boghossian et al. 2005), rAAV-Leptin-treated rats lost weight while rAAV-GFPtreated rats gained weight during the 18 week duration of study. The respective changes in weight occurred during the first few weeks following vector administration, stabilizing thereafter. At study termination, rAAV-Leptintreated rats weighed less than rAAV-GFP-treated rats and had lower abdominal WAT weight, serum leptin, and serum IGF1. In contrast, rAAV-Leptin treatment had minimal long-term effects on bone mass, density, and architecture or serum markers of bone turnover.

In the present study, the initial reduction in body weight following leptin gene therapy was associated with lower $(-12.3 \%)$ energy intake compared to rAAV-GFP treatment. The initial increase in energy intake in rAAVGFP-treated rats following vector administration likely represents a rebound in food consumption following a surgery-induced reduction in food intake. In support, historical data indicate that age-matched ad lib-fed rats consume $\sim 18 \mathrm{~g} /$ day of diet (Iwaniec et al. 2011). In contrast, an attenuated rebound in food intake was apparent in rAAVLeptin treated rats. Once weight stabilized at a lower level, energy intake continued to be lower $(-7 \%)$ in the rAAVLeptin-treated rats than in rAAV-GFP-treated rats. These findings are consistent with previous long-duration gene therapy studies (Dhillon et al. 2001a, Torto et al. 2006). The regulatory actions of leptin to reduce energy intake are mediated through a hypothalamic relay involving activation of leptin receptors on orexigenic NPY and anorectic proopiomelanocortin-expressing neurons (Schwartz et al. 1996a, Forbes et al. 2001). Morbidly obese leptin-deficient ob/ob mice are hyperphagic and express increased hypothalamic mRNA levels for NPY (Schwartz et al. 1996b) and

Table 2 Effects of hypothalamic rAAV-Leptin therapy on cancellous bone volume fraction (bone volume/tissue volume) and cancellous bone architecture in lumbar vertebra

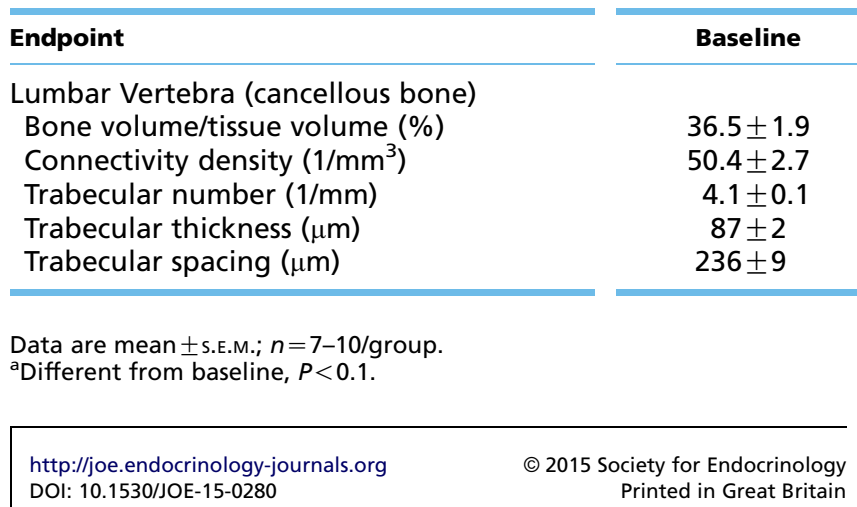

\begin{tabular}{cccc}
\hline rAAV-GFP & rAAV-leptin & FDR-adjusted $P$ value \\
$28.9 \pm 2.05^{a}$ & & $32.7 \pm 1.8$ & \\
$52.1 \pm 3.1$ & $56.0 \pm 4.8$ & 0.087 \\
$3.6 \pm 0.13^{a}$ & $3.9 \pm 0.1$ & 0.625 \\
$79 \pm 2$ & $82 \pm 3$ & 0.090 \\
$273 \pm 11^{a}$ & $252 \pm 8$ & 0.182 \\
& & 0.087
\end{tabular}


these abnormalities are reversed following leptin treatment (Duan et al. 2007). At study termination, hypothalamic leptin gene expression was elevated in the rAAV-Leptin gene therapy group but significant differences in hypothalamic NPY gene expression were not observed between treatment groups. It is possible, however, that reduced NPY expression was associated with initial weight loss following vector administration (Bagnasco et al. 2002, Beretta et al. 2002).

Genetic obesity in leptin-deficient ob/ob mice is reversed following administration of leptin (Levin et al. 1996). In contrast, normal rats and mice exhibit age-related weight gain in spite of increased leptin levels. The failure of increased serum leptin to prevent further weight gain is generally attributed to blood brain barrier leptin resistance and/or hypothalamic leptin resistance (Frederich et al. 1995, Banks et al. 1996, 1999, Van Heek et al. 1997, Burguera et al. 2000, Sahu 2002, Bluher \& Mantzoros 2004, Bray 2004). Gene therapy bypasses blood brain barrier leptin resistance by direct introduction of leptin into the hypothalamus. The present study demonstrates the longterm efficacy of this approach in inducing weight loss and maintaining lower body weight in skeletally mature female rats. Factors such as diet composition and physical activity may impact the efficacy of hypothalamic leptin gene therapy in preventing excessive weight gain (Dube et al. 2002, 2008, Shapiro et al. 2008). Nevertheless, our findings in rats consuming normal diet suggest that increasing hypothalamic leptin levels overcomes leptin resistance to prevent adult-onset weight gain.

The elevated leptin mRNA levels that we detected in the hypothalamus 18 weeks following administration of rAAV-Leptin contrast with the notable reduction in serum leptin. The $77 \%$ reduction in serum leptin observed in the present study was associated with a similar decrease $(-80 \%)$ in abdominal WAT weight. This finding is consistent with the concept that leptin levels reflect fat stores (Hickey et al. 1996). It is notable that the magnitude of lowering WAT weight $(-80 \%)$ following rAAV-Leptin treatment greatly exceeded lowering body weight $(-17 \%)$. This is consistent with previous reports indicating that rAAV-Leptin treatment preferentially reduces adipose tissue while preserving lean tissue (Dhillon et al. 2001b). Furthermore, leptin administration has been shown to increase muscle mass in leptin-deficient ob/ob mice (Bartell et al. 2011) and aged C57BL6 mice (Hamrick et al. 2010).

rAAV-Leptin treatment lowered serum IGF1 levels. IGF1 is an important mediator of the anabolic actions of growth hormone. A primary target of growth hormone is the liver, where the hormone stimulates IGF1 secretion through the activation of the hepatic growth hormone receptor. In turn, IGF1 modifies growth hormone secretion through a negative-feedback loop (Clemmons 2007). Increased IGF1 levels and decreased growth hormone secretion are associated with obesity (Garten et al. 2012), whereas decreased IGF1 levels are associated with caloric restriction (Rasmussen et al. 1995, Mitterberger et al. 2011). Thus, the observed decrease in serum IGF1 could reflect an increase in growth hormone secretion. However, we did not detect a change in growth hormone levels with treatment, a finding consistent with the lack of an effect of caloric restriction on growth hormone levels reported in obese subjects in some human studies (Rasmussen et al. 1995, Mitterberger et al. 2011).

A substantial proportion of serum IGF1 is nonhepatic in origin (Liu et al. 2000). Adipocytes produce IGF1 (D'Esposito et al. 2012), potentially contributing to reduced growth hormone secretion associated with obesity. Leptin gene therapy did not impact IGF1 mRNA levels in WAT but the dramatic decrease in WAT following gene therapy may have contributed to the reduction in serum levels of this growth factor.

The decrease in serum IGF1 following rAAV-Leptin administration in normal rats contrasts with the response of ob/ob mice to leptin. Whereas, acute intravenously administered leptin had no effect on serum IGF1 (Burcelin et al. 1999), chronic intracerebroventricular leptin administration to ob/ob mice was reported to increase serum IGF1 levels (Bartell et al. 2011). The latter long-term response may be related to normalization of growth hormone secretion in ob/ob mice (Sinha et al. 1975, Luque et al. 2007).

Elevated blood leptin is a risk factor for cardiovascular disease, diabetic kidney disease and several cancers (Cheung et al. 2010, Cleary et al. 2010, Hou \& Luo 2011, Hoda et al. 2012, Nishimura et al. 2012) and high serum IGF1 levels are associated with increased cancer risk (Ribeiro et al. 2004, Cleary et al. 2009, Chaves \& Saif 2011). Thus, reduction in serum leptin and IGF1, in addition to weight loss, may be positive side effects of increasing hypothalamic leptin (Moore et al. 2008, Olivo-Marston et al. 2009, Wu et al. 2010, Lee et al. 2010b).

Leptin increases bone nodule formation in vitro (Gordeladze et al. 2002) and increases bone formation when delivered to ob/ob mice by either intermittent subcutaneous administration (Turner et al. 2013a) or intracerebroventricular infusion (Bartell et al. 2011). Furthermore, hypothalamic leptin gene therapy increases osteoblast-lined bone perimeter and serum osteocalcin, and normalizes bone architecture in ob/ob mice without increasing serum leptin (Turner et al. 2013a). Although ob/ob mice have reduced

Published by Bioscientifica Ltd 
osteoblast number and activity, the effects of leptin deficiency on bone metabolism appear to be partially compensated for by factors related to development of morbid obesity. Specifically, normalizing weight gain in $\mathrm{ob} / \mathrm{ob}$ mice by dietary restriction and thermoneutral housing accentuated their skeletal phenotype (Turner $e t$ al. 2014), characterized by reduced bone growth and turnover, low total bone mass and mild osteopetrosis.

In contrast to the notable effects of leptin to increase bone formation in leptin-deficient mice, increased leptin levels associated with moderate weight gain had no effect on bone metabolism in skeletally mature rats (Turner \& Iwaniec 2010). Similarly, prevention of weight gain in skeletally mature rats by mild caloric restriction had no negative impact on bone formation (Turner \& Iwaniec 2010). In the present long-term study, reduced serum leptin induced by hypothalamic leptin gene therapy was not associated with altered serum markers of bone turnover or accelerated age-related bone loss. Taken together, these findings suggest that the bone anabolic effects of leptin are most pronounced at low serum concentrations of the hormone and as a consequence hyperleptinemia does not confer additional positive skeletal benefits.

Bone mass in growing rodents is tightly coupled to body size (Iwaniec et al. 2009). Cessation of linear bone growth occurs in rats as a consequence of formation of bone bridges that penetrate the growth plate, rendering further growth unfeasible (Martin et al. 2003). The time table for linear growth cessation varies among bones but growth generally ceases in female Sprague Dawley rats by 8 months of age. As in adult humans, periosteal bone formation continues in long bones of skeletally mature rats at a very slow rate throughout life (Briot et al. 2010, Stathopoulos et al. 2011). Weight typically increases in rodents following skeletal maturity but the impact of weight changes on the skeleton has not been thoroughly explored (Iwaniec \& Turner 2013). In the present study, bone area measured by DXA and cortical bone volume measured by $\mu \mathrm{CT}$ exhibited an upward trend in rAAV-GFP rats whereas these parameters remained at baseline control levels in rAAV-Leptin rats. The strong association between bone size and body weight typically observed in WT mice are preserved in leptin-deficient ob/ob mice (Iwaniec et al. 2009), a finding which suggests that increased bone size in aging rAAV-GFP rats is due to their increased body weight.

As expected, age-related cortical bone loss was not observed in the present study. In humans, a negative intracortical bone remodeling balance contributes to age-related bone loss (Seeman 2013). A limitation of rodents is that they do not exhibit intracortical bone remodeling. As a consequence, age-related cortical bone loss is limited to resorption occurring on the endocortical bone surface. Bone loss associated with aging at this site is slow and compensated for by addition of bone onto the periosteal surface (Turner et al. 2013b).

As in adult humans, cancellous bone remodeling continues throughout adult life in skeletally mature rats (Iwaniec \& Turner 2013). An imbalance between bone formation and bone resorption is responsible for persistent bone loss during aging in both species. The trend for agerelated cancellous bone loss observed in femur and lumbar vertebra in the present study is consistent with previous results where significant bone loss is noted between 8 months and 2 years of age (Turner et al. 2001, 2013b). Caloric restriction accelerates age-related cancellous bone loss (Bodnar et al. 2012, Mardon et al. 2008a,b), a finding consistent with the hypothesis that a decrease in leptin levels in the context of low energy availability contributes to bone loss. Leptin treatment, in spite of drastically reducing body weight in growing ob/ob mice, results in increased longitudinal bone growth, increased bone formation, increased bone resorption, a net increase in bone mass and normalization of bone microarchitecture (Hamrick et al. 2005, Iwaniec et al. 2007, Bartell et al. 2011, Turner et al. 2013a).

In summary, hypothalamic leptin gene therapy, in spite of inducing weight loss, had minimal effects on bone mass, density, microarchitecture or biochemical markers of bone turnover. The lack of an effect of rAAV-Leptin gene therapy on bone in skeletally mature rats contrasts with the negative skeletal effects associated with similar weight loss induced by caloric restriction (Turner \& Iwaniec 2011). There has been remarkable recent progress in gene therapy, including treatment of diseases of the CNS (Leone et al. 2012, Kantor et al. 2014). Our findings suggest that interventions, including hypothalamic leptin gene therapy, targeted toward increasing hypothalamic leptin levels have the potential to overcome leptin resistance and lower body weight without negatively impacting the skeleton.

\section{Declaration of interest}

The authors declare that there is no conflict of interest that could be perceived as prejudicing the impartiality of the research reported.

\section{Funding}

This work was supported by NIH AR 060913 and DOD W81XWH-04-1-0701.

Published by Bioscientifica Ltd. 


\section{References}

Arounleut P, Bowser M, Upadhyay S, Shi XM, Fulzele S, Johnson MH, Stranahan AM, Hill WD, Isales CM \& Hamrick MW 2013 Absence of functional leptin receptor isoforms in the POUND (Lepr(db/lb)) mouse is associated with muscle atrophy and altered myoblast proliferation and differentiation. PLOS ONE 8 e72330. (doi:10.1371/journal.pone. 0072330)

Bagnasco M, Dube MG, Kalra PS \& Kalra SP 2002 Evidence for the existence of distinct central appetite, energy expenditure, and ghrelin stimulation pathways as revealed by hypothalamic site-specific leptin gene therapy. Endocrinology 143 4409-4421. (doi:10.1210/en.2002-220505)

Banks WA \& Lebel CR 2002 Strategies for the delivery of leptin to the CNS. Journal of Drug Targeting 10 297-308. (doi:10.1080/1061186029 0031895)

Banks WA, Kastin AJ, Huang W, Jaspan JB \& Maness LM 1996 Leptin enters the brain by a saturable system independent of insulin. Peptides $\mathbf{1 7}$ 305-311. (doi:10.1016/0196-9781(96)00025-3)

Banks WA, DiPalma CR \& Farrell CL 1999 Impaired transport of leptin across the blood-brain barrier in obesity. Peptides 20 1341-1345. (doi:10.1016/S0196-9781(99)00139-4)

Bartell SM, Rayalam S, Ambati S, Gaddam DR, Hartzell DL, Hamrick M, She JX, Della-Fera MA \& Baile CA 2011 Central (ICV) leptin injection increases bone formation, bone mineral density, muscle mass, serum IGF-1, and the expression of osteogenic genes in leptin-deficient ob/ob mice. Journal of Bone and Mineral Research 26 1710-1720. (doi:10.1002/ jbmr.406)

Benjamini Y \& Hochberg Y 1995 Controlling the false discover rate: a practical and powerful approach to multiple testing. Journal of the Royal Statistical Society. Series B $\mathbf{5 7} 289-300$.

Beretta E, Dube MG, Kalra PS \& Kalra SP 2002 Long-term suppression of weight gain, adiposity, and serum insulin by central leptin gene therapy in prepubertal rats: effects on serum ghrelin and appetiteregulating genes. Pediatric Research 52 189-198. (doi:10.1203/ 00006450-200208000-00010)

Bjorbaek C, Elmquist JK, Frantz JD, Shoelson SE \& Flier JS 1998 Identification of SOCS-3 as a potential mediator of central leptin resistance. Molecular Cell 1 619-625. (doi:10.1016/S10972765(00)80062-3)

Bluher S \& Mantzoros CS 2004 The role of leptin in regulating neuroendocrine function in humans. Journal of Nutrition $\mathbf{1 3 4}$ 2469S-2474S.

Bodnar M, Skalicky M, Viidik A \& Erben RG 2012 Interaction between exercise, dietary restriction and age-related bone loss in a rodent model of male senile osteoporosis. Gerontology 58 139-149. (doi:10.1159/ 000329113)

Boghossian S, Lecklin A, Torto R, Kalra PS \& Kalra SP 2005 Suppression of fat deposition for the life time with gene therapy. Peptides 26 1512-1519. (doi:10.1016/j.peptides.2005.03.039)

Boghossian S, Ueno N, Dube MG, Kalra P \& Kalra S 2007 Leptin gene transfer in the hypothalamus enhances longevity in adult monogenic mutant mice in the absence of circulating leptin. Neurobiology of Aging 28 1594-1604. (doi:10.1016/j.neurobiolaging.2006.08.010)

Bray GA 2004 Medical consequences of obesity. Journal of Clinical Endocrinology and Metabolism 89 2583-2589. (doi:10.1210/ jc.2004-0535)

Briot K, Kolta S, Fechtenbaum J, Said-Nahal R, Benhamou CL \& Roux C 2010 Increase in vertebral body size in postmenopausal women with osteoporosis. Bone 47 229-234. (doi:10.1016/j.bone.2010.03.020)

Burcelin R, Kamohara S, Li J, Tannenbaum GS, Charron MJ \& Friedman JM 1999 Acute intravenous leptin infusion increases glucose turnover but not skeletal muscle glucose uptake in ob/ob mice. Diabetes $\mathbf{4 8}$ 1264-1269. (doi:10.2337/diabetes.48.6.1264)

Burguera B, Couce ME, Curran GL, Jensen MD, Lloyd RV, Cleary MP \& Poduslo JF 2000 Obesity is associated with a decreased leptin transport across the blood-brain barrier in rats. Diabetes 49 1219-1223. (doi:10.2337/diabetes.49.7.1219)

Carter S, Caron A, Richard D \& Picard F 2013 Role of leptin resistance in the development of obesity in older patients. Clinical Interventions in Aging 8 829-844. (doi:10.2147/CIA.S36367)

Cauley JA 2013 Public health impact of osteoporosis. Journals of Gerontology Series A: Biological Sciences and Medical Sciences 68 1243-1251. (doi:10.1093/gerona/glt093)

Chaves J \& Saif MW 2011 IGF system in cancer: from bench to clinic. Anti-Cancer Drugs 22 206-212. (doi:10.1097/CAD.0b013e32834258a1)

Cheung WW, Paik KH \& Mak RH 2010 Inflammation and cachexia in chronic kidney disease. Pediatric Nephrology 25 711-724. (doi:10.1007/ s00467-009-1427-z)

Cleary MP, Ray A, Rogozina OP, Dogan S \& Grossmann ME 2009 Targeting the adiponectin:leptin ratio for postmenopausal breast cancer prevention. Frontiers in Bioscience 1 329-357. (doi:10.2741/s30)

Cleary MP, Grossmann ME \& Ray A 2010 Effect of obesity on breast cancer development. Veterinary Pathology 47 202-213. (doi:10.1177/ 0300985809357753)

Clemmons DR 2007 Value of insulin-like growth factor system markers in the assessment of growth hormone status. Endocrinology and Metabolism Clinics of North America 36 109-129. (doi:10.1016/j.ecl.2006.11.008)

D'Esposito V, Passaretti F, Hammarstedt A, Liguoro D, Terracciano D, Molea G, Canta L, Miele C, Smith U \& Beguinot F 2012 Adipocytereleased insulin-like growth factor- 1 is regulated by glucose and fatty acids and controls breast cancer cell growth in vitro. Diabetologia $\mathbf{5 5}$ 2811-2822. (doi:10.1007/s00125-012-2629-7)

Devlin MJ, Cloutier AM, Thomas NA, Panus DA, Lotinun S, Pinz I, Baron R, Rosen CJ \& Bouxsein ML 2010 Caloric restriction leads to high marrow adiposity and low bone mass in growing mice. Journal of Bone and Mineral Research 25 2078-2088. (doi:10.1002/jbmr.82)

Dhillon H. 2000 Effects of recombinant adeno-associated virus encoding leptin on body weight regulation and energy homeostasis. p 171: University of Florida.

Dhillon H, Ge Y, Minter RM, Prima V, Moldawer LL, Muzyczka N, Zolotukhin S, Kalra PS \& Kalra SP 2000 Long-term differential modulation of genes encoding orexigenic and anorexigenic peptides by leptin delivered by rAAV vector in ob/ob mice. Relationship with body weight change. Regulatory Peptides 92 97-105. (doi:10.1016/S01670115(00)00155-5)

Dhillon H, Kalra SP \& Kalra PS 2001a Dose-dependent effects of central leptin gene therapy on genes that regulate body weight and appetite in the hypothalamus. Molecular Therapy 4 139-145. (doi:10.1006/mthe. 2001.0427)

Dhillon H, Kalra SP, Prima V, Zolotukhin S, Scarpace PJ, Moldawer LL, Muzyczka N \& Kalra PS $2001 b$ Central leptin gene therapy suppresses body weight gain, adiposity and serum insulin without affecting food consumption in normal rats: a long-term study. Regulatory Peptides 99 69-77. (doi:10.1016/S0167-0115(01)00237-3)

Duan J, Choi YH, Hartzell D, Della-Fera MA, Hamrick M \& Baile CA 2007 Effects of subcutaneous leptin injections on hypothalamic gene profiles in lean and ob/ob mice. Obesity 15 2624-2633. (doi:10.1038/ oby.2007.314)

Dube MG, Beretta E, Dhillon H, Ueno N, Kalra PS \& Kalra SP 2002 Central leptin gene therapy blocks high-fat diet-induced weight gain, hyperleptinemia, and hyperinsulinemia: increase in serum ghrelin levels. Diabetes 51 1729-1736. (doi:10.2337/diabetes.51.6.1729)

Dube MG, Torto R \& Kalra SP 2008 Increased leptin expression selectively in the hypothalamus suppresses inflammatory markers CRP and IL-6 in leptin-deficient diabetic obese mice. Peptides 29 593-598. (doi:10.1016/ j.peptides.2008.01.001)

Elfhag K \& Rossner S 2005 Who succeeds in maintaining weight loss? A conceptual review of factors associated with weight loss maintenance and weight regain Obesity Reviews 6 67-85. (doi:10.1111/j.1467-789X. 2005.00170.x) 
Forbes S, Bui S, Robinson BR, Hochgeschwender U \& Brennan MB 2001 Integrated control of appetite and fat metabolism by the leptinproopiomelanocortin pathway. PNAS 98 4233-4237. (doi:10.1073/ pnas.071054298)

Franssen FM, O'Donnell DE, Goossens GH, Blaak EE \& Schols AM 2008 Obesity and the lung: 5. Obesity and COPD. Thorax 63 1110-1117. (doi:10.1136/thx.2007.086827)

Frederich RC, Hamann A, Anderson S, Lollmann B, Lowell BB \& Flier JS 1995 Leptin levels reflect body lipid content in mice: evidence for diet-induced resistance to leptin action. Nature Medicine 1 1311-1314 (doi:10.1038/nm1295-1311)

Friedman JM 2010 A tale of two hormones. Nature Medicine 16 1100-1106. (doi:10.1038/nm1010-1100)

Garten A, Schuster S \& Kiess W 2012 The insulin-like growth factors in adipogenesis and obesity. Endocrinology and Metabolism Clinics of North America 41 283-295, v-vi. (doi:10.1016/j.ecl.2012.04.011)

Gat-Yablonski G \& Phillip M 2008 Leptin and regulation of linear growth. Current Opinion in Clinical Nutrition and Metabolic Care 11 303-308. (doi:10.1097/MCO.0b013e3282f795cf)

Gat-Yablonski G, Ben-Ari T, Shtaif B, Potievsky O, Moran O, Eshet R, Maor G, Segev Y \& Phillip M 2004 Leptin reverses the inhibitory effect of caloric restriction on longitudinal growth. Endocrinology 145 343-350. (doi:10.1210/en.2003-0910)

Goldstone AP, Howard JK, Lord GM, Ghatei MA, Gardiner JV, Wang ZL, Wang RM, Girgis SI, Bailey CJ \& Bloom SR 2002 Leptin prevents the fall in plasma osteocalcin during starvation in male mice. Biochemistry and Biophysics Research Communications 295 475-481. (doi:10.1016/ S0006-291X(02)00697-6)

Gordeladze JO, Drevon CA, Syversen U \& Reseland JE 2002 Leptin stimulates human osteoblastic cell proliferation, de novo collagen synthesis, and mineralization: Impact on differentiation markers, apoptosis, and osteoclastic signaling. Journal of Cellular Biochemistry $\mathbf{8 5}$ 825-836. (doi:10.1002/jcb.10156)

Hamann A \& Matthaei S 1996 Regulation of energy balance by leptin. Experimental and Clinical Endocrinology \& Diabetes 104 293-300. (doi:10.1055/s-0029-1211457)

Hamrick MW, Della-Fera MA, Choi YH, Pennington C, Hartzell D \& Baile CA 2005 Leptin treatment induces loss of bone marrow adipocytes and increases bone formation in leptin-deficient ob/ob mice. Journal of Bone and Mineral Research 20 994-1001. (doi:10.1359/JBMR.050103)

Hamrick MW, Herberg S, Arounleut P, He HZ, Shiver A, Qi RQ, Zhou L, Isales CM \& Mi QS 2010 The adipokine leptin increases skeletal muscle mass and significantly alters skeletal muscle miRNA expression profile in aged mice. Biochemistry and Biophysics Research Communications 400 379-383. (doi:10.1016/j.bbrc.2010.08.079)

Hickey MS, Israel RG, Gardiner SN, Considine RV, McCammon MR, Tyndall GL, Houmard JA, Marks RH \& Caro JF 1996 Gender differences in serum leptin levels in humans. Biochemical and Molecular Medicine 59 1-6. (doi:10.1006/bmme.1996.0056)

Hoda MR, Theil G, Mohammed N, Fischer K \& Fornara P 2012 The adipocyte-derived hormone leptin has proliferative actions on androgen-resistant prostate cancer cells linking obesity to advanced stages of prostate cancer. Journal of Oncology 2012 article 280386. (doi:10.1155/ 2012/280386)

Hou N \& Luo JD 2011 Leptin and cardiovascular diseases. Clinical and Experimental Pharmacology \& Physiology 38 905-913. (doi:10.1111/ j.1440-1681.2011.05619.x)

Iwaniec UT, Turner RT. 2013 Animal Models for Osteoporosis.

Iwaniec UT, Boghossian S, Lapke PD, Turner RT \& Kalra SP 2007 Central leptin gene therapy corrects skeletal abnormalities in leptin-deficient ob/ob mice. Peptides 28 1012-1019. (doi:10.1016/j.peptides.2007. 02.001)

Iwaniec UT, Dube MG, Boghossian S, Song H, Helferich WG, Turner RT \& Kalra SP 2009 Body mass influences cortical bone mass independent of leptin signaling. Bone 44 404-412. (doi:10.1016/j.bone.2008.10.058)
Iwaniec UT, Boghossian S, Trevisiol CH, Wronski TJ, Turner RT \& Kalra SP 2011 Hypothalamic leptin gene therapy prevents weight gain without long-term detrimental effects on bone in growing and skeletally mature female rats. Journal of Bone and Mineral Research 26 1506-1516. (doi:10.1002/jbmr.365)

Kantor B, McCown T, Leone P \& Gray SJ 2014 Clinical applications involving CNS gene transfer. Advances in Genetics 87 71-124. (doi:10.1016/B978-0-12-800149-3.00002-0)

Knobelspies H, Zeidler J, Hekerman P, Bamberg-Lemper S \& Becker W 2010 Mechanism of attenuation of leptin signaling under chronic ligand stimulation. BMC Biochemistry 11 2. (doi:10.1186/1471-2091-11-2)

Lee JS, Visser M, Tylavsky FA, Kritchevsky SB, Schwartz AV, Sahyoun N, Harris TB, Newman AB \& Health ABCS 2010a Weight loss and regain and effects on body composition: the Health. Aging, and Body Composition Study. Journals of Gerontology Series A: Biological Sciences and Medical Sciences 65 78-83. (doi:10.1093/gerona/glp042)

Lee C, Safdie FM, Raffaghello L, Wei M, Madia F, Parrella E, Hwang D, Cohen P, Bianchi G \& Longo VD $2010 b$ Reduced levels of IGF-I mediate differential protection of normal and cancer cells in response to fasting and improve chemotherapeutic index. Cancer Research 70 1564-1572. (doi:10.1158/0008-5472.CAN-09-3228)

Leone P, Shera D, McPhee SW, Francis JS, Kolodny EH, Bilaniuk LT, Wang DJ, Assadi M, Goldfarb O, Goldman HW et al. 2012 Long-term follow-up after gene therapy for canavan disease. Science Translational Medicine 4 165ra163. (doi:10.1126/scitranslmed.3003454)

Levin N, Nelson C, Gurney A, Vandlen R \& de Sauvage F 1996 Decreased food intake does not completely account for adiposity reduction after ob protein infusion. PNAS 93 1726-1730. (doi:10.1073/pnas.93.4. 1726)

Liu JL, Yakar S \& LeRoith D 2000 Mice deficient in liver production of insulin-like growth factor I display sexual dimorphism in growth hormone-stimulated postnatal growth. Endocrinology 141 4436-4441. (doi:10.1210/endo.141.12.7825)

Low S, Chin MC \& Deurenberg-Yap M 2009 Review on epidemic of obesity. Annals of the Academy of Medicine, Singapore 38 57-59.

Luque RM, Huang ZH, Shah B, Mazzone T \& Kineman RD 2007 Effects of leptin replacement on hypothalamic-pituitary growth hormone axis function and circulating ghrelin levels in ob/ob mice. American Journal of Physiology. Endocrinology and Metabolism 292 E891-E899. (doi:10.1152/ajpendo.00258.2006)

Magliano M 2008 Obesity and arthritis. Menopause International 14 149-154. (doi:10.1258/mi.2008.008018)

Mardon J, Habauzit V, Trzeciakiewicz A, Davicco MJ, Lebecque P, Mercier S, Tressol JC, Horcajada MN, Demigne C \& Coxam V 2008a Influence of high and low protein intakes on age-related bone loss in rats submitted to adequate or restricted energy conditions. Calcified Tissue International 82 373-382. (doi:10.1007/s00223-008-9125-6)

Mardon J, Zangarelli A, Walrand S, Davicco MJ, Lebecque P, Demigne C, Horcajada MN, Boirie Y \& Coxam V 2008b Impact of energy and casein or whey protein intake on bone status in a rat model of age-related bone loss. British Journal of Nutrition 99 764-772. (doi:10.1017/ S0007114507837469)

Martin EA, Ritman EL \& Turner RT 2003 Time course of epiphyseal growth plate fusion in rat tibiae. Bone 32 261-267. (doi:10.1016/ S8756-3282(02)00983-3)

Mitterberger MC, Mattesich M, Klaver E, Piza-Katzer H \& Zwerschke W 2011 Reduced insulin-like growth factor-I serum levels in formerly obese women subjected to laparoscopic-adjustable gastric banding or diet-induced long-term caloric restriction. Journals of Gerontology Series A: Biological Sciences and Medical Sciences 66 1169-1177. (doi:10.1093/ gerona/glr149)

Moore T, Carbajal S, Beltran L, Perkins SN, Yakar S, Leroith D, Hursting SD \& Digiovanni J 2008 Reduced susceptibility to two-stage skin carcinogenesis in mice with low circulating insulin-like growth factor I levels. Cancer Research 68 3680-3688. (doi:10.1158/0008-5472. CAN-07-6271) 
Morris DL \& Rui L 2009 Recent advances in understanding leptin signaling and leptin resistance. American Journal of Physiology. Endocrinology and Metabolism 297 E1247-E1259. (doi:10.1152/ajpendo.00274.2009)

Nishimura K, Soda T, Nakazawa S, Yamanaka K, Hirai T, Kishikawa H \& Ichikawa Y 2012 Serum adiponectin and leptin levels are useful markers for prostate cancer screening after adjustments for age, obesity-related factors, and prostate volume. Minerva Urologica e Nefrologica 64 199-208.

Olivo-Marston SE, Hursting SD, Lavigne J, Perkins SN, Maarouf RS, Yakar S \& Harris CC 2009 Genetic reduction of circulating insulin-like growth factor-1 inhibits azoxymethane-induced colon tumorigenesis in mice. Molecular Carcinogenesis 48 1071-1076. (doi:10.1002/mc.20577)

Rasmussen MH, Juul A, Kjems LL, Skakkebaek NE \& Hilsted J 1995 Lack of stimulation of 24-hour growth hormone release by hypocaloric diet in obesity. Journal of Clinical Endocrinology and Metabolism 80 796-801.

Ribeiro R, Lopes C \& Medeiros R 2004 Leptin and prostate: implications for cancer prevention-overview of genetics and molecular interactions. European Journal of Cancer Prevention 13 359-368. (doi:10.1097/ 00008469-200410000-00002)

Rosenbaum M \& Leibel RL 201420 years of leptin: role of leptin in energy homeostasis in humans. Journal of Endocrinology 223 T83-T96. (doi:10.1530/JOE-14-0358)

Sahu A 2002 Resistance to the satiety action of leptin following chronic central leptin infusion is associated with the development of leptin resistance in neuropeptide Y neurones. Journal of Neuroendocrinology $\mathbf{1 4}$ 796-804. (doi:10.1046/j.1365-2826.2002.00840.x)

Scarpace PJ \& Tumer N 2001 Peripheral and hypothalamic leptin resistance with age-related obesity. Physiology \& Behavior 74 721-727. (doi:10.1016/S0031-9384(01)00616-3)

Schwartz MW, Seeley RJ, Campfield LA, Burn P \& Baskin DG 1996 a Identification of targets of leptin action in rat hypothalamus. Journal of Clinical Investigation 98 1101-1106. (doi:10.1172/JCI118891)

Schwartz MW, Baskin DG, Bukowski TR, Kuijper JL, Foster D, Lasser G, Prunkard DE, Porte D Jr, Woods SC, Seeley RJ et al. 1996b Specificity of leptin action on elevated blood glucose levels and hypothalamic neuropeptide Y gene expression in ob/ob mice. Diabetes 45 531-535. (doi:10.2337/diab.45.4.531)

Seeman E 2013 Age- and menopause-related bone loss compromise cortical and trabecular microstructure. Journals of Gerontology Series A: Biological Sciences and Medical Sciences 68 1218-1225. (doi:10.1093/gerona/ glt071)

Shapiro A, Matheny M, Zhang Y, Tumer N, Cheng KY, Rogrigues E, Zolotukhin S \& Scarpace PJ 2008 Synergy between leptin therapy and a seemingly negligible amount of voluntary wheel running prevents progression of dietary obesity in leptin-resistant rats. Diabetes $\mathbf{5 7}$ 614-622. (doi:10.2337/db07-0863)

Shapses SA \& Riedt CS 2006 Bone, body weight, and weight reduction: what are the concerns? Journal of Nutrition 136 1453-1456.

Sinha YN, Salocks CB \& Vanderlaan WP 1975 Prolactin and growth hormone secretion in chemically induced and genetically obese mice. Endocrinology 97 1386-1393. (doi:10.1210/endo-97-6-1386)

Stathopoulos KD, Katsimbri P, Atsali E, Metania E, Zoubos AB \& Skarantavos G 2011 Age-related differences of bone mass, geometry, and strength in treatment-naive postmenopausal women. A tibia pQCT study. Journal of Clinical Dentistry 14 33-40. (doi:10.1016/j.jocd.2010. 11.004)

Stunes AK, Westbroek I, Gordeladze JO, Gustafsson BI, Reseland JE \& Syversen U 2012 Systemic leptin administration in supraphysiological doses maintains bone mineral density and mechanical strength despite significant weight loss. Endocrinology 153 2245-2253. (doi:10.1210/en. 2011-1848)
Talbott SM, Cifuentes M, Dunn MG \& Shapses SA 2001 Energy restriction reduces bone density and biomechanical properties in aged female rats. Journal of Nutrition 131 2382-2387.

Team RDC. 2010 R: A languare and environment for statistical computing. Vienna, Austria: R Foundation for Statistical Computing.

Thomsen JS, Laib A, Koller B, Prohaska S, Mosekilde L \& Gowin W 2005 Stereological measures of trabecular bone structure: comparison of 3D micro computed tomography with $2 \mathrm{D}$ histological sections in human proximal tibial bone biopsies. Journal of Microscopy 218 171-179. (doi:10.1111/j.1365-2818.2005.01469.x)

Torto R, Boghossian S, Dube MG, Kalra PS \& Kalra SP 2006 Central leptin gene therapy blocks ovariectomy-induced adiposity. Obesity 14 1312-1319. (doi:10.1038/oby.2006.149)

Turner RT \& Iwaniec UT 2010 Moderate weight gain does not influence bone metabolism in skeletally mature female rats. Bone $\mathbf{4 7} 631-635$. (doi:10.1016/j.bone.2010.06.010)

Turner RT \& Iwaniec UT 2011 Low dose parathyroid hormone maintains normal bone formation in adult male rats during rapid weight loss. Bone 48 726-732. (doi:10.1016/j.bone.2010.12.034)

Turner RT, Kidder LS, Kennedy A, Evans GL \& Sibonga JD 2001 Moderate alcohol consumption suppresses bone turnover in adult female rats. Journal of Bone and Mineral Research 16 589-594. (doi:10.1359/jbmr. 2001.16.3.589)

Turner RT, Kalra SP, Wong CP, Philbrick KA, Lindenmaier LB, Boghossian S \& Iwaniec UT 2013a Peripheral leptin regulates bone formation. Journal of Bone and Mineral Research 28 22-34. (doi:10.1002/jbmr.1734)

Turner RT, Iwaniec UT, Andrade JE, Branscum AJ, Neese SL, Olson DA, Wagner L, Wang VC, Schantz SL \& Helferich WG $2013 b$ Genistein administered as a once-daily oral supplement had no beneficial effect on the tibia in rat models for postmenopausal bone loss. Menopause 20 677-686. (doi:10.1097/gme.0b013e31827d44df)

Turner RT, Philbrick KA, Wong CP, Olson DA, Branscum AJ \& Iwaniec UT 2014 Morbid obesity attenuates the skeletal abnormalities associated with leptin deficiency in mice. Journal of Endocrinology 223 M1-M15. (doi:10.1530/JOE-14-0224)

Van Heek M, Compton DS, France CF, Tedesco RP, Fawzi AB, Graziano MP, Sybertz EJ, Strader CD \& Davis HR Jr 1997 Diet-induced obese mice develop peripheral, but not central, resistance to leptin. Journal of Clinical Investigation 99 385-390. (doi:10.1172/JCI119171)

Villalon KL, Gozansky WS, Van Pelt RE, Wolfe P, Jankowski CM, Schwartz RS \& Kohrt WM 2011 A losing battle: weight regain does not restore weight loss-induced bone loss in postmenopausal women. Obesity 19 2345-2350. (doi:10.1038/oby.2011.263)

Welch BL 1951 On the comparison of several mean values: an alternative approach. Biometrika 38 330-336. (doi:10.1093/biomet/38.3-4.330)

Wu T, Gao X, Chen M \& van Dam RM 2009 Long-term effectiveness of dietplus-exercise interventions vs. diet-only interventions for weight loss: a meta-analysis. Obesity Reviews 10 313-323. (doi:10.1111/j.1467-789X. 2008.00547.x)

Wu Y, Brodt P, Sun H, Mejia W, Novosyadlyy R, Nunez N, Chen X, Mendoza A, Hong SH, Khanna C et al. 2010 Insulin-like growth factor-I regulates the liver microenvironment in obese mice and promotes liver metastasis. Cancer Research 70 57-67. (doi:10.1158/0008-5472. CAN-09-2472)

Yaskin J, Toner RW \& Goldfarb N 2009 Obesity management interventions a review of the evidence. Population Health Management 12 305-316. (doi:10.1089/pop.2008.0049)

Zolotukhin S, Byrne BJ, Mason E, Zolotukhin I, Potter M, Chesnut K, Summerford C, Samulski RJ \& Muzyczka N 1999 Recombinant adenoassociated virus purification using novel methods improves infectious titer and yield. Gene Therapy 6 973-985. (doi:10.1038/sj.gt.3300938)

Received in final form 21 August 2015

Accepted 14 September 2015

Accepted Preprint published online 14 September 2015 http://joe.endocrinology-journals.org

DOI: $10.1530 / \mathrm{JOE}-15-0280$ (c) 2015 Society for Endocrinology Printed in Great Britain
Published by Bioscientifica Ltd. 